\title{
PENGARUH BUDAYA ORGANISASI, GAYA KEPEMIMPINAN DAN KOMITMEN ORGANISASI TERHADAP KINERJA PEGAWAI
}

(Studi Pada: Pegawai Badan Narkotika Nasional Provinsi Bengkulu)

\author{
Haryati Utami \\ Dosen Program Studi Manajemen Fakultas Ekonomi Universitas Dehasen Bengkulu \\ Umi.haryatiutami@gmail.com
}

\begin{abstract}
ABSTRAK
Haryati Utami; Tujuan dari penelitian ini adalah untuk mengetahui pengaruh budaya organisasi, gaya kepemimpinan dan komitmen organisasi terhadap kinerja karyawan Badan Narkotika Nasional di Provinsi Bengkulu baik secara simultan maupun parsial. Penelitian ini menggunakan regresi linier berganda dengan responden 59 karyawan dari karyawan Badan Narkotika Nasional di Provinsi Bengkulu. Metode pengumpulan data yang digunakan adalah kuesioner dan wawancara. Metode analisis data kuantitatif dilakukan dengan mencari nilai rata-rata (mean) dari skala (scoring) dari data penelitian pengolahan data dan menggunakan SPSS 17 software. Hasil ini dari uji hipotesis penelitian menunjukkan bahwa budaya organisasi, gaya kepemimpinan dan komitmen organisasi terhadap kinerja karyawan Badan Narkotika Nasional di Provinsi Bengkulu memiliki pengaruh baik secara simultan maupun parsial.
\end{abstract}

\section{ABSTRACT}

Haryati Utami; The purpose of this study was to determine the effect of organizational culture, leadership style and organizational commitment to the performance of the employees of National Narcotics Board in Bengkulu Province either simultaneously or partially. This research is used multiple linear regression with respondents 59 employees of the employees of National Narcotics Board in Bengkulu Province. Data collection methods used were questionnaires and interviews. Methods of quantitative data analysis is done by finding the average value (mean) of the scaling (scoring) of data and processing research data using SPSS 17 software. These results from the study hypothesis test indicate that the organizational culture, leadership style and organizational commitment to the performance of the employees of National Narcotics Board in Bengkulu province has an influence either simultaneously or partially.

\section{Keywords: Organizational Culture, Leadership Style And Organizational Commitment And Employee Performance.}

\section{PENDAHULUAN}

Nota Kesepahaman antara Pemerintah Daerah Provinsi Bengkulu dengan Badan Narkotika Nasional Nomor 03/2011SKB/54/IV/2011BNN tentang Kerjasama Pelaksanaan Percepatan Kapasitas BNN di Daerah dan Keputusan Kepala Badan Narkotika Nasional Nomor KEP/73/VI/2011/BNN tentang Pengangkatan dalam Jabatan di Lingkungan Badan Narkotika Nasional Provinsi Bengkulu mengamanatkan perubahan status Pelaksana Harian Badan Narkotika Provinsi Bengkulu menjadi Badan Narkotika Nasional Provinsi Bengkulu sebagai instansi pemerintah pusat/ vertikal (PERDA Provinsi Bengkulu Nomor 04 : 2012). Peraturan ini berkosekuensi pada dilakukannya penataan kembali Struktur Organisasi dan Tata Kerja, Lembaga Lain Perangkat Daerah Provinsi Bengkulu dalam hal ini merujuk pada Peraturan Kepala Badan Narkotika Nasional Nomor : PER/04/V/BNN tanggal 12 Mei 2010 tentang Organisasi dan Tata Kerja Badan Narkotika Nasional Provinsi dan Badan Narkotika Nasional Kab/Kota.

Seiring dengan vertikalisasi pada Badan Narkotika Nasional Provinsi Bengkulu terjadi pula perubahan aturan-aturan yang digunakan sebagai pedoman dalam pelaksanaan tugas pokok dan fungsinya sebagai aparatur sektor publik. Perubahan tersebut tentunya membutuhkan proses sosialisasi untuk nilai-nilai yang baru seiring dengan perubahan sistem baik berupa aturan formal atau tertulis maupun aturan-aturan yang bersifat implisit. Vertikalisasi tersebut juga berpengaruh pada rantai komando yang dulunya desentralisasi menjadi sentralisasi. Perubahan pola pelaporan akuntabilitas dan tata kelola serta budaya Badan Narkotika Nasional. Sebelumnya kegiatan-kegiatan yang dilakukan pada Badan Narkotika Nasional dulunya merujuk pada tata cara pemerintah daerah baik secara administrasi maupun secara teknis misalnya dilihat dari tata cara surat-menyurat, tata cara pelaksanaan teknis lapangan dan lain-lain. Oleh karena itu para pegawai sering melakukan konsultasi kepada rekan kerja maupun kepada pimpinannya dalam rangka pelaporan akuntabilitas dan tata kelola sesuai dengan peraturan yang terbaru. 
Para pegawai yang telah mendapatkan bimbingan teknis sesuai dengan bidang masingmasing memberikan sharing ilmu sebagai upaya ikut andil dalam proses sosialisasi perubahan tersebut. Hal tersebut mendorong suasana yang akrab antar pegawai serta membentuk kerja sama antara sesama pegawai. Selain itu, kerja sama antara sesama pegawai juga tampak pada tiap bidang. Misalnya pada bidang pencegahan, para pegawai bekerja sama dalam melaksanakan kegiatan dilapangan berupa sosialisasi P4GN kepada para siswa, mahasiswa, intansi pemerintah dan swasta. Para pegawai bekerja sama dari menyiapkan kontak pin, alat tulis dan piagam untuk peserta, absen peserta, menyiapkan sampai dengan memasang spanduk, menyiapkan sound system dan alat pendukung lainnya, menyiapkan snack dan makan peserta serta menyusun acara sehingga dapat berjalan sesuai dengan SOP yang ada.

Vertikalisasi tersebut juga berimbas gaya kepemimpinan di Badan Narkotika Nasional Provinsi Bengkulu yang awalnya dipimpin oleh pegawai negeri sipil kemudian dipimpin oleh POLRI. Perberdaan gaya kepemimpinan tersebut dapat dilihat dari proses komunikasi yang dilakukan pimpinan untuk memandu, menuntun, membimbing, membangun, memberikan arahan kepada para pegawainya untuk memperoleh kinerja yang optimal. Badan Narkotika Nasional Provinsi Bengkulu setelah dipimpin oleh POLRI arahan yang diberikan sebagian mengadopsi gaya kemimpinan POLRI dalam hal tuntunan disiplin pegawai sehingga apabila terdapat pelanggaran disiplin, para pegawai dikenakan sanksi yang tegas.

Badan Narkotika Provinsi (BNP) Bengkulu sebelum vertikal untuk mencapai visi dan misinya Kepala Pelaksana Harian (Kalakhar) jarang melimpahkan wewenang terhadap bawahannya dan juga semua pekerjaan dan tanggung jawab dilimpahkan kepada pegawai. Sedangkan setelah vertikalisasi Badan Narkotika Nasional Provinsi Bengkulu dalam pencapaian visi dan misinya, terdapat urutan komando yang memiliki kewenangan langsung dan tanggung jawab dari kepala Badan Narkotika Nasional Provinsi Bengkulu. Kebijakan dalam hal teknis lapangan di ambil langsung oleh kepala Badan Narkotika Nasional Provinsi Bengkulu. Kebijakan inilah yang akan menjadi patokan para pegawai dalam melaksanakan kegiatan-kegiatan yang menjadi program kerja dalam pencapaian visi dan misi Badan Narkotika Nasional Provinsi Bengkulu. Komunikasi yang dilakukan oleh kepala Badan Narkotika Nasional Provinsi Bengkulu bersifat formal biasanya dengan mengadakan rapat untuk memberikan intruksi dan arahan kepada para pegawai, intruksi dan arahan tersebut yang kemudian akan dilaksanakan oleh seluruh pegawai Badan Narkotika Nasional Provinsi Bengkulu.

\section{LANDASAN TEORI KINERJA}

Kinerja seorang pegawai merupakan hal yang bersifat individual, karena setiap pegawai mempunyai tingkat kemampuan yang berbeda - beda dalam mengerjakan tugasnya. Pihak manajemen dapat mengukur kinerja kualifikasi para pegawai berdasarkan kinerja dari masing - masing pegawai itu sendiri. Kinerja terdiri dari banyak komponen dan bukan merupakan hasil yang dapat dilihat pada saat itu juga. Pada dasarnya kinerja merupakan sesuatu hal yang bersifat individual, karena setiap pegawai memiliki tingkat kemampuan yang berbeda dalam mengerjakan tugasnya. Kinerja tergantung pada kombinasi antara kemampuan, usaha, dan kesempatan yang diperoleh. Hal ini berarti bahwa kinerja merupakan hasil kerja pegawai dalam bekerja untuk periode waktu tertentu dan penekanannya pada hasil kerja yang diselesaikan pegawai dalam periode waktu tertentu. (Timpe, 1993:59).

Menurut Janseen, Onne (1998) variabel kinerja karyawan dibentuk dari tiga indikator yaitu :

1. Kualitas kerja,

2. Kemampuan karyawan,

3. Kreativitas, dan

4. Ketepatan waktu

Kinerja adalah suatu hasil kerja yang dicapai seseorang dalam melaksanakan tugas-tugas yang dibebankan kepadanya yang didasarkan atas kecakapan, pengalaman dan kesungguhan serta waktu (Janseen, Onne.1998). Dalam penelitian ini, kinerja yang diteliti adalah kinerja di lingkungan pada Badan Narkotika Nasional Provinsi Bengkulu setelah adanya vertikalisasi yang diukur berdasarkan kualitas kerja, kemampuan karyawan, kreativitas dan ketepatan waktu.

\section{BUDAYA ORGANISASI}

Menurut Schein (1992), budaya organisasi adalah pola dasar yang diterima oleh organisasi untuk bertindak dan memecahkan masalah, membentuk karyawan yang mampu beradaptasi dengan lingkungan dan mempersatukan anggota-anggota organisasi. Untuk itu harus diajarkan kepada anggota termasuk anggota yang baru sebagai suatu cara yang benar dalam mengkaji, berpikir dan merasakan masalah yang dihadapi. Pada kesempatan yang berbeda Cushway dan Lodge (2000:59) mengemukakan budaya organisasi merupakan sistem nilai organisasi dan akan mempengaruhi cara pekerjaan dilakukan dan cara 
para karyawan berperilaku. Dapat disimpulkan bahwa yang dimaksud dengan budaya organisasi dalam penelitian ini adalah sistem nilai organisasi yang dianut oleh anggota organisasi, yang kemudian mempengaruhi cara bekerja dan berperilaku dari para anggota organisasi.

Menurut Hofstede, Geert (2004) budaya organisasi adalah suatu persepsi bersama yang dianut oleh anggota-anggota organisasi itu. Dalam penelitian ini, budaya organisasi yang diteliti adalah budaya yang tertanam dalam lingkungan pada Badan Narkotika Nasional Provinsi Bengkulu setelah vertikalisasi yang diukur berdasarkan profesionalisme, jarak manajemen, percaya pada rekan dan integritas.

\section{Hubungan antara Budaya Organisasi dengan Kinerja Pegawai}

Kotter dan Heskett (Stoner et. al, 1996) menyatakan budaya yang kuat sering dikatakan membantu kinerja karena menciptakan suatu tingkat motivasi yang luar biasa dalam diri pegawai. Sementara Kotter, JP dan J.L. Heskett (1997) menjelaskan telah dilakukan penelitian terhadap 207 perusahaan di dunia yang aktifitasnya berada di Amerika Serikat. Penelitian tersebut menghasilkan empat kesimpulan, yaitu:

1. Budaya organisasi dapat mempunyai dampak yang berarti dalam kinerja organisasi jangka panjang.

2. Budaya organisasi mungkin akan menjadi suatu faktor yang bahkan lebih penting lagi dalam menentukan keberhasilan organisasi dalam dasawarsa yang akan datang. Budaya yang menomorsatukan kinerja mengakibatkan dampak kinerja negatif dengan berbagai alasan. Alasan utama adalah kecenderungan menghambat organisasi- organisasi dalam menerima prubahan-perubahan taktik dan strategi yang dibutuhkan.

3. Budaya organisasi yang menghambat peningkatan kinerja jangka panjang cukup banyak, budayabudaya mudah berkembang bahkan dalam organisasi-organisasi yang penuh dengan orang-orang pandai dan berakal sehat. Budaya-budaya yang mendorong perilaku yang tidak tepat dan menghambat perubahan kearah strategi yang lebih tepat, cenderung muncul perlahan-lahan dan tanpa disadari dalam waktu bertahun-tahun, biasanya sewaktu oranisasi berkinerja baik.

4. Walaupun sulit untuk diubah, budaya organisasi dapat dibuat agar bersifat lebih meningkatkan kinerja.

\section{GAYA KEPEMIMPINAN}

Robbins (1996) menyatakan bahwa kepemimpinan merupakan kemampuan untuk mempengaruhi suatu kelompok kearah tercapainya suatu tujuan. Kepemimpinan adalah pengaruh antara pribadi yang dijalankan dalam situasi tertentu, serta diarahkan melalui proses komunikasi ke arah pencapaian satu atau beberapa tujuan tertentu. Kepeminpinan menyangkut proses pengaruh sosial yang disengaja dijalankan oleh seseorang terhadap orang lain untuk menstruktur aktivitas dan pengaruh di dalam sebuah kelompok atau organsiasi. Kartini (1994:92) menyatakan bahwa fungsi kepemimpinan adalah memandu, menuntun, membimbing, membangun, memberi atau membangunkan motivasi kerja, mengemudikan organisasi dan menjaring jaringan komunikasi dan membawa pengikutnya kepada sasaran yang ingin dituju dengan ketentuan waktu dan perencanaan. Menurut Singh-Sengupa (Ma'sud:2004) gaya kepemimpinan adalah pengaruh antara pribadi yang dijalankan dalam situasi tertentu, serta diarahkan melalui proses komunikasi ke arah pencapaian satu atau beberapa tujuan tertentu. Dalam penelitian ini, gaya kepemimpinan yang diteliti adalah gaya kepemimpinan Pegawai Negeri Sipil di lingkungan pada Badan Narkotika Nasional Provinsi Bengkulu setelah adanya vertikalisasi yang diukur berdasarkan pengaruh ideal, inspirasi, perkembangan intelektor dan perhatian pribadi.

\section{Hubungan Gaya Kepemimpinan dengan Kinerja Pegawai}

Dalam teori jalur tujuan (Path Goal Theory) yang dikembangkan oleh Robert House (Kreitner dan Kinicki. 2005) menyatakan bahwa gaya kepemimpinan mendorong kinerja yang lebih tinggi dengan cara memberikan kegiatan-kegiatan yang mempengaruhi bawahannya agar percaya bahwa hasil yang berharga bisa dicapai dengan usaha yang serius. Kepemimpinan yang berlaku secara universal menghasilkan tingkat kinerja dan kepuasan bawahan yang tinggi. Dalam situasi yang berbeda mensyaratkan gaya kepemimpinan yaitu karakteristik personal dan kekuatan lingkungan. Teori ini juga menggambarkan bagaimana persepsi harapan dipengaruhi oleh hubungan kontijensi diantara gaya kepemimpinan dan berbagai sikap dan perilaku karyawan. Perilaku pemimpin memberikan motivasi sampai tingkat (1) mengurangi halangan jalan yang mengganggu pencapaian tujuan, (2) memberikan panduan dan dukungan yang dibutuhkan oleh para karyawan, dan (3) mengaitkan penghargaan yang berarti terhadap pencapaian tujuan.

\section{Komitmen Organisasi}

Keberhasilan pengelolaan organisasi sangatlah ditentukan oleh keberhasilan dalam mengelola SDM. Seberapa jauh komitmen karyawan terhadap organisasi ttiga mereka bekerja, sangatlah menentukan 
organisasi itu dalam mencapai tujuannya. Dalam dunia kerja komitmen karyawan terhadap organisasi sangatlah penting sehingga sampai-sampai beberapa organisasi berani memasukkan unsur komitmen sebagai salah satu syarat untuk memegang jabatan/posisi yang ditawarkan dalam iklan lowongan pekerjaan. Sayangnya meskipun demikian tidak jarang pengusaha maupun karyawan masih belum memahami arti komitmen secara sungguh-sungguh. Padahal pemahaman tersebut sangat penting agar tercipta kondisi kerja yang kondusif sehingga organisasi dapat berjalan secara efisien dan efektif. Dalam rangka memahami apa sebenarnya komitmen karyawan terhadap organisasi beberapa ahli memberikan pengertian dan pandangan mereka.

Allen dan Meyer (1993), mendefinisikan komitmen organisasi sebagai rasa identifikasi, keterlibatan, dan loyalitas yang dinyatakan oleh seorang karyawan

terhadap organisasinya. Dalam penelitian ini khusus pada pegawai PEMDA Bengkulu yang dipekerjakan pada Badan Narkotika Nasional Provinsi Bengkulu yang diukur berdasarkan affective, continuance dan normatif.

\section{Hubungan antara Komitmen Organisasi dengan Kinerja Pegawai}

Bagi pegawai pemerintah yang memilki komitmen organisasi yang tinggi, pencapaian tujuan organisasi merupakan hal yang penting. Nouri dan Parker (1998) mengemukakan bahwa komitmen organisasi yang kuat dalam diri individu akan menyebabkan individu tersebut berusaha keras mencapai tujuan organisasi dan kemauan mengerahkan usaha atas nama organisasi guna meningkatkan kinerja. Dengan kata lain, individu dengan komitmen organisasi tinggi akan menunjukkan kinerja yang baik dalam upaya tercapainya tujuan dari organisasi tersebut.

\section{METODE PENELITIAN}

\section{Metode Pengumpulan Data}

Metode pengumpulan data pada subyek penelitian ditentukan dengan menggunakan sensus yaitu, subyek dari seluruh pegawai pada Badan Narkotika Nasional Provinsi Bengkulu sejumlah 59 orang yang akan dijadikan responden dalam penelitian. Adapun metode penelitian yang digunakan yaitu dengan memberikan kuesioner dan mengcross cek hasil tabulasi kuesioner dengan mewawancara empat orang pemimpin di Badan Narkotika Nasional Provinsi Bengkulu. Pengolahan data menggunakan software SPSS 17.

\section{Hasil Regresi Linear Berganda Analisis Uji Annova}

Bedasarkan pengolahan data primer yang dilakukan mengunakkan SPSS 17 sehingga diperoleh hasil analisis regresi sebagai berikut :

$$
Y=0.367 X_{1}+0.226 X_{2}+0.339 X_{3}
$$

dimana,

$$
\begin{array}{lll}
\mathrm{Y} & : & \text { Kinerja Pegawai } \\
\mathrm{X}_{1} & : & \text { Budaya Organisasi } \\
\mathrm{X}_{2} & : & \text { Gaya Kepemimpinan } \\
\mathrm{X}_{3} & : & \text { Komitmen Organisasi }
\end{array}
$$

Persamaan (1.1) diatas menunjukkan bahwa koefisien regresi bernilai positif menyatakan bahwa dengan mengasumsikan bahwa ketika variabel Budaya Organisasi, Gaya Kepemimpinan dan Komitmen Organisasi mengalami peningkatan maka variabel Kinerja Pegawai juga akan mengalami peningkatan. Dalam penelitian ini, Budaya Organisasi memberikan komtribusi pengaruh sebesar 0.367 , sementara Gaya Kepemimpinan memberikan komtribusi pengaruh sebesar 0.226 dan Komitmen Organisasi memberikan komtribusi pengaruh sebesar 0.339 terhadap Kinerja Pegawai pada Badan Narkotika Nasional Provinisi Bengkulu.

\section{Uji Hipotesis 1}

Dalam penelitian ini, hipotesis 1 yang akan diuji adalah sebagai berikut :

$\boldsymbol{H 1}_{\mathbf{0}}$ : Budaya Organisasi, Gaya Kepemimpinan dan Komitmen Organisasi tidak berpengaruh pada kinerja Pegawai Badan Narkotika Nasional Provinsi Bengkulu

H1 $1_{1}$ : Budaya Organisasi, Gaya Kepemimpinan dan Komitmen Organisasi berpengaruh pada kinerja Pegawai Badan Narkotika Nasional Provinsi Bengkulu

dalam penelitian ini menggunakan kriteria penolakan hipotesis jika $\alpha>0.05$ maka $\boldsymbol{H} \mathbf{1}_{\mathbf{0}}$ diterima dan $\boldsymbol{H} \mathbf{1}_{\mathbf{1}}$ ditolak.

Adapun hasil pengujian statistik F menggunakan software SPSS 17 dapat di lihat pada tabel berikut ini: 
Tabel 1. Hasil Uji Statistik t

ANOVA $^{\mathrm{b}}$

\begin{tabular}{|l|r|r|r|r|r|}
\hline \multicolumn{1}{|c|}{ Model } & Sum of Squares & Df & Mean Square & F & Sig. \\
\hline 1 & 197.788 & 3 & 65.929 & 30.275 & $.000^{\mathrm{a}}$ \\
& Regression & 119.771 & 55 & 2.178 & \\
\\
Residual & 317.559 & 58 & & & \\
Total & & & \\
\hline
\end{tabular}

a. Predictors: (Constant), KO, BO, GK

b. Dependent Variable: Kin

Tabel 1. menunjukkan nilai annova (uji statistik F) sebesar 30.275 dengan signifikansi sebesar 0.00 artinya $\boldsymbol{H} \mathbf{1}_{\mathbf{0}}$ ditolak dan $\boldsymbol{H} \mathbf{1}_{\mathbf{1}}$ diterima dengan kata lain Budaya Organisasi, Gaya Kepemimpinan dan Komitmen Organisasi berpengaruh terhadap kinerja Pegawai Badan Narkotika Nasional Provinsi Bengkulu. Hal tersebut berindikasi bahwa pada Badan Narkotika Nasional Provinsi Bengkulu terdapat pengaruh Budaya Organisasi, Gaya Kepemimpinan dan Komitmen Organisasi terhadap kinerja pegawai secara bersamaan.

\section{Uji Hipotesis 2}

Dalam penelitian ini, hipotesis 2 yang akan diuji adalah sebagai berikut :

$H 2_{0}$ : Budaya Organisasi tidak berpengaruh pada kinerja Pegawai Badan Narkotika Nasional Provinsi Bengkulu

H2 1 : Budaya Organisasi berpengaruh pada kinerja Pegawai Badan Narkotika Nasional Provinsi Bengkulu

dalam penelitian ini menggunakan kriteria penolakan hipotesis jika $\alpha>0.05$ maka $\boldsymbol{H} \mathbf{2}_{\mathbf{0}}$ diterima dan $\boldsymbol{H} \mathbf{2}_{\mathbf{1}}$ ditolak. ini:

Adapun hasil pengujian statistik t menggunakan software SPSS 17 dapat di lihat pada tabel berikut

Tabel 2. Hasil Uji Statistik t

Coefficients $^{\mathrm{a}}$

\begin{tabular}{|c|c|c|c|c|c|c|}
\hline & \multirow[b]{2}{*}{ Model } & \multicolumn{2}{|c|}{ Unstandardized Coefficients } & Standardized Coefficients & \multirow[b]{2}{*}{$\mathrm{t}$} & \multirow[b]{2}{*}{ Sig. } \\
\hline & & B & Std. Error & Beta & & \\
\hline \multirow[t]{4}{*}{1} & (Constant) & .202 & 3.123 & & .065 & .949 \\
\hline & BO & .346 & .102 & .367 & 3.400 & .001 \\
\hline & GK & .302 & .148 & .226 & 2.033 & .047 \\
\hline & КО & .479 & .150 & .339 & 3.199 & .002 \\
\hline
\end{tabular}

a. Dependent Variable: Kin

Tabel 2. di atas, diperoleh nilai uji statistik $\mathrm{t}$ untuk budaya organisasi dengan nilai $\mathrm{t}=3.400$ signifikan sebesar 0.001 artinya $\boldsymbol{H} \mathbf{2}_{\mathbf{0}}$ ditolak dan $\boldsymbol{H} \mathbf{2}_{\mathbf{1}}$ diterima dengan kata lain Budaya Organisasi berpengaruh pada kinerja Pegawai Badan Narkotika Nasional Provinsi Bengkulu. Hal tersebut menunjukkan pada Badan Narkotika Nasional Provinsi Bengkulu terdapat pengaruh Budaya Organisasi terhadap kinerja pegawai secara parsial.

\section{Uji Hipotesis 3}

Dalam penelitian ini, hipotesis 3 yang akan diuji adalah sebagai berikut:

H3 $_{\mathbf{0}}$ : Gaya Kepemimpinan berpengaruh pada kinerja Pegawai Badan Narkotika Nasional Provinsi Bengkulu

H3 $3_{1}$ Gaya Kepemimpinan berpengaruh pada kinerja Pegawai Badan Narkotika Nasional Provinsi Bengkulu

dalam penelitian ini menggunakan kriteria penolakan hipotesis jika $\alpha>0.05$ maka $\boldsymbol{H 3}_{\mathbf{0}}$ diterima dan $\boldsymbol{H} \mathbf{3}_{\mathbf{1}}$ ditolak.

Adapun hasil pengujian statistik t menggunakan software SPSS 17 dapat di lihat pada Tabel 2. Hasil Uji Statistik $t$ diatas sehingga diperoleh nilai uji statistik $t$ untuk Gaya Kepemimpinan dengan nilai $t=2.033$ signifikan sebesar 0.047 artinya $\boldsymbol{H 3}_{\mathbf{0}}$ ditolak dan $\boldsymbol{H} \mathbf{3}_{\mathbf{1}}$ diterima dengan kata lain Gaya Kepemimpinan berpengaruh pada kinerja Pegawai Badan Narkotika Nasional Provinsi Bengkulu. Hal tersebut menunjukkan pada Badan Narkotika Nasional Provinsi Bengkulu terdapat pengaruh Gaya Kepemimpinan terhadap kinerja pegawai secara parsial 


\section{Uji Hipotesis 4}

Dalam penelitian ini, hipotesis 4 yang akan diuji adalah sebagai berikut:

$\boldsymbol{H 4}_{\mathbf{0}}$ : Komitmen Organisasi tidak berpengaruh pada kinerja Pegawai Badan Narkotika Nasional Provinsi Bengkulu

H4 1 : Komitmen Organisasi berpengaruh pada kinerja Pegawai Badan Narkotika Nasional Provinsi Bengkulu

dalam penelitian ini menggunakan kriteria penolakan hipotesis jika $\alpha>0.05$ maka $\boldsymbol{H 4}_{\mathbf{0}}$ diterima dan $\boldsymbol{H 4}_{\mathbf{1}}$ ditolak.

Adapun hasil pengujian statistik t menggunakan software SPSS 17 dapat di lihat pada Tabel 2. Hasil Uji Statistik $t$ diatas sehingga diperoleh nilai uji statistik $t$ untuk gaya kepemimpinan dengan nilai $t=3.199$ signifikan sebesar 0.02 artinya $\boldsymbol{H 4}_{\mathbf{0}}$ ditolak dan $\boldsymbol{H 4}_{\mathbf{1}}$ diterima dengan kata lain Komitmen Organisasi berpengaruh pada kinerja Pegawai Badan Narkotika Nasional Provinsi Bengkulu. Hal tersebut menunjukkan pada Badan Narkotika Nasional Provinsi Bengkulu terdapat pengaruh Komitmen Organisasi terhadap kinerja pegawai secara parsial

\section{HASIL PENELITIAN}

Hasil pengujian hipotesis 1 menegaskan adanya pengaruh Budaya Organisasi, Gaya Kepemimpinan dan Komitmen Organisasi berpengaruh terhadap kinerja para pegawai Badan Narkotika Nasional Provinsi Bengkulu. Hal ini mempertegas bahwa kinerja pegawai Badan Narkotika Nasional Provinsi Bengkulu dipengaruhi variabel-variabel tersebut.

Berdasarkan penelitian, jika ditinjau dari hasil kuesioner pada penelitian ini, variabel kinerja pada Tabel 4.1 menunjukkan bahwa pada Badan Narkotika Nasional Provinsi Bengkulu rata-rata pegawai telah meningkatkan potensi diri dengan mengikuti pelatihan akan tetapi masih ada pegawai yang belum mengikuti pelatihan meningkatkan potensi diri. Badan Narkotika Nasional Provinsi Bengkulu sering menerima undangan untuk menjadi peserta pelatihan dan bimbingan teknis bagi staf dari Badan Narkotika Nasional sebagai upaya sinkronisasi program pusat dan daerah. Bimbingan teknis tersebut hampir menyeluruh berbasis komputerisasi dan teknologi informasi. Misalnya bimbingan teknis untuk pelaporan Sistem Informasi Narkoba (SIN), bimbingan teknis untuk aplikator pada aplikasi Monitoring dan Evaluasi (MONEV) kegiatan, bimbingan teknis untuk aplikator pada aplikasi Inpes No. 12 tahun 2011, bimbingan teknis untuk aplikator pada aplikasi SIMAK,SAKPA dan SILABI serta bebagai bimbingan teknis lainnya Hal tersebut sering menjadi kendala bagi beberapa pegawai pemda yang dipekerjakan karena pegawai tersebut belum memiliki kompetensi untuk mengoperasikan komputer.

Setelah dilakukan wawancara dengan 4 orang pimpinan pada Badan Narkotika Nasional Provinsi Bengkulu diperoleh bahwa pegawai yang belum memiliki kompetensi untuk mengoperasikan komputer sebagian besar para pegawai pemda yang sudah paroh baya sehingga sulit untuk belajar pengoperasian komputer, kemudian pegawai tersebut diberikan tanggung jawab bersifat teknis misalnya mengagendakan surat masuk dan surat keluar, mengarsipkan surat, dan mengantarkan surat. Hal tesebut dilakukan untuk mengoptimalkan seluruh kinerja pegawai sesuai dengan kemampuan yang dimilikinya.

Dengan kata lain menurut respoden dari pegawai Badan Narkotika Nasional Provinsi Bengkulu menunjukkan adanya peningkatan kinerja misalnya pada pegawai yang dulunya sering menunda-nunda pekerjaan kemudian setelah adanya batas waktu tugas yang diberikan pegawai tersebut berusaha maksimal menyelesaikannya serta adanya koordinasi dan kerja sama yang baik antar bidang pada Badan Narkotika Nasional Provinsi Bengkulu sehingga dapat menyelesaikan tugas sesuai dengan deadline.

Hasil pengujian hipotesis 2 menegaskan adanya pengaruh Budaya Organisasi berpengaruh terhadap Kinerja para pegawai Badan Narkotika Nasional Provinsi Bengkulu. Hal ini mempertegas bahwa kinerja pegawai Badan Narkotika Nasional Provinsi Bengkulu dipengaruhi Budaya Organisasi. Hasil penelitian ini konsisten dengan hasil penelitian Jenifer Chatman dan Bersade (1997) yang hasil penelitiannya mengindikasikan Budaya Organisasi berpengaruh positif terhadap Kinerja.

Selanjutnya pada variabel Budaya Organisasi pada Tabel 4.2, diperoleh bahwa setiap bidang di Badan Narkotika Nasional Provinsi Bengkulu, terdiri dari pegawai negeri sipil baik tenaga medis maupun non medis dan aparatur POLRI yang memiliki latar bekalang budaya yang berbeda. Kegiatan yang ada pada Badan Narkotika Nasional Provinsi Bengkulu terdiri dari kegiatan yang hanya dilakukan bidang tertentu saja maupun kegiatan yang melibatkan seluruh pegawai Badan Narkotika Nasional Provinsi Bengkulu. Rapat yang diadakan untuk para kepala bagian (kabag)/ kepala bidang (kabid) serta kepala seksi (kasi) biasanya berupa tata cara pemerintahan yang bersifat teknis dan administratif dalam pelaksanaan kegiatan Badan Narkotika Nasional Provinsi Bengkulu untuk masing-masing bidang lalu hasilnya ditindak lanjuti 
para kepala bagian (kabag)/ kepala bidang (kabid) serta kepala seksi (kasi) tersebut untuk di sampaikan kepada seluruh staf masing-masing bidang agar diimplementasikan sesuai dengan instruksi dan arahan yang diberikan Kepala Badan Narkotika Nasional Provinsi Bengkulu.

Sementara rapat yang diadakan untuk seluruh pegawai (rapat staf) biasanya berupa arahan teknis dan administratif dalam pelaksanaan kegiatan yang melibatkan seluruh pegawai dilingkungan Badan Narkotika Nasional Provinsi Bengkulu, misalnya pelaksanaan Upacara Peringatan Hari Anti Narkoba Internasional (HANI), Pagelaran Seni Budaya dalam upaya pencegahan penyalahgunaan narkoba, dan lainlain. Adapun tujuan rapat yang diadakan untuk seluruh pegawai (rapat staf) bertujuan untuk mengkoordinir seluruh pegawai antar bidang agar dapat bekerja sama untuk mensukseskan seluruh kegiatan tersebut sesuai dengan arahan kepala sebagai upaya optimalisasi kinerja pada Badan Narkotika Nasional Provinsi Bengkulu.

Pada sisi lain, adanya indikasi bahwa keputusan yang diambil oleh Kepala pada Badan Narkotika Nasional Provinsi Bengkulu bersifat sentralisasi. Pada Badan Narkotika Nasional Provinsi Bengkulu yang mengalami vertikalisasi mengindikasikan adanya perubahan rantai komando yang dulunya desentralisasi menjadi sentralisasi karena semua peraturan merujuk pada peraturan Badan Narkotika Nasional sesuai dengan isi dari diterbitkan Peraturan Presiden RI No. 23 Tahun 2010 Tentang Badan Narkotika Nasional.

Setelah dilakukan wawancara dengan 4 orang pimpinan pada Badan Narkotika Nasional Provinsi Bengkulu diperoleh bahwa Badan Narkotika Nasional Provinsi Bengkulu keputusan dan arah kebijakan yang diambil merujuk pada peraturan pusat, tidak lagi menginduk pada pemerintah daerah baik dalam hal yang bersifat administratif maupun teknis sesuai dengan Peraturan Presiden RI No. 23 Tahun 2010 Tentang Badan Narkotika Nasional. Pelaksanaan program kerja antara Badan Narkotika Nasional Provinsi Bengkulu dan Badan Narkotika Nasional merujuk pada Peraturan Kepala Badan Narkotika Nasional Nomor PER/04/V/BNN tahun 2010 tentang Organisasi dan Tata Laksanan Badan Narkotika Nasional Provinsi dan Badan Narkotika Nasional Kota/Kab.

Dengan kata lain menurut respoden dari pegawai Badan Narkotika Nasional Provinsi Bengkulu, Budaya Organisasi memilki pengaruh yang terkait terhadap Kinerja. Budaya organisasi pada Badan Narkotika Nasional Provinsi Bengkulu berpengaruh terhadap kinerja, misalnya dapat dilihat dari Budaya Organisasi yang ada pada Badan Narkotika Nasional Provinsi Bengkulu berpengaruh terhadap kinerja. Meskipun pada Badan Narkotika Nasional Provinsi Bengkulu setiap bidang terdiri dari pegawai negeri sipil baik tenaga medis maupun non medis dan aparatur POLRI yang memiliki latar bekalang budaya yang berbeda akan tetapi adanya koordinasi yang baik dari seluruh pegawai agar dapat bekerja sama untuk mensukseskan seluruh kegiatan sesuai dengan arahan kepala sebagai upaya optimalisasi kinerja pada Badan Narkotika Nasional Provinsi Bengkulu.

Hasil pengujian hipotesis 3 menegaskan adanya pengaruh Gaya Kepemimpinan berpengaruh terhadap Kinerja para pegawai Badan Narkotika Nasional Provinsi Bengkulu. Hal ini mempertegas bahwa kinerja pegawai Badan Narkotika Nasional Provinsi Bengkulu dipengaruhi Gaya Kepemimpinan. Hasil penelitian ini konsisten dengan hasil penelitian Shea, M (1999) yang hasil penelitiannya menunjukan Gaya Kepemimpinan berpengaruh positif terhadap Kinerja.

Kemudian untuk variabel Gaya Kepemimpinan pada Tabel 2. berindikasi bahwa Kepala Badan Narkotika Nasional Provinsi Bengkulu memberikan perhatian khusus pada pegawai tertentu saja untuk meningkatkan kinerja. Dalam hal ini, Gaya Kepemimpinan pada Badan Narkotika Nasional Provinsi Bengkulu yang dipimpin oleh POLRI memberikan perhatian khusus pada beberapa pegawai yang melanggar disiplin. Oleh karena itu, pegawai yang melanggar disiplin tersebut diberikan sanksi yang tegas sesuai dengan instruksi yang diberikan oleh Kepala Badan Narkotika Nasional Provinsi Bengkulu secara langsung untuk dilakukan pembinaan, disamping itu para pegawai juga diberi kesempatan oleh kepala Badan Narkotika Nasional Provinsi Bengkulu untuk mengikuti pelatihan guna meningkatkan kinerja para pegawai.

Setelah dilakukan wawancara dengan 4 orang pimpinan pada Badan Narkotika Nasional Provinsi Bengkulu diperoleh bahwa para pegawai yang melanggar disiplin memperoleh perhatian khusus karena terus dipantau sejauh mana pegawai tersebut berangsur-angsur disiplin dengan diberikan instruksi dan arahan langsung oleh kepala Badan Narkotika Nasional Provinsi Bengkulu akan tetapi bila pegawai tidak megindahkan instruksi tersebut maka dikenakan sanksi yang tegas dengan harapan dapat menimbulkan efek jera sehingga para pegawai Badan Narkotika Nasional Provinsi Bengkulu disiplin baik terhadap peraturan yang berlaku juga disiplin terhadap deadline tugas yang diemban untuk meningkatkan kinerja.

Hasil pengujian hipotesis 4 menegaskan adanya pengaruh Komitmen Organisasi berpengaruh terhadap Kinerja para pegawai Badan Narkotika Nasional Provinsi Bengkulu. Hal ini mempertegas bahwa kinerja pegawai Badan Narkotika Nasional Provinsi Bengkulu dipengaruhi Komitmen Organisasi. Hasil penelitian ini konsisten dengan hasil penelitian Saman (2005) yang hasil penelitiannya menunjukan komitemen organisasi berpengaruh positif terhadap kinerja. 
Disamping itu, variabel Komitmen Organisasi pada Tabel 2. berindikasi bahwa beberapa pegawai Badan Narkotika Nasional Provinsi Bengkulu memiliki perasaaan bangga menjadi bagian dari Badan Narkotika Nasional Provinsi Bengkulu sehingga muncul kemauan untuk tetap tinggal dan membina hubungan sosial namun masih terdapat pegawai yang hanya sekedar ikut-ikutan untuk dipekerjakan oleh pemda Provinsi Bengkulu menjadi pegawai pada Badan Narkotika Nasional Provinsi Bengkulu yang belum memiliki rasa tanggung jawab yang penuh terhadap tugas yang diemban dan kemudian berdampak pada kurang optimalnya kinerja para pegawai. Oleh karena itu para pegawai pemda yang dipekerjakan tersebut dirasa perlu untuk menentukan pilihan bergabung menjadi pegawai vertikal dilingkungan Badan Narkotika Nasional Provinsi Bengkulu atau kembali pada satuan kerja pemda Provinsi Bengkulu.

Setelah dilakukan wawancara dengan 4 orang pimpinan pada Badan Narkotika Nasional Provinsi Bengkulu diperoleh bahwa adanya penentuan pilihan untuk menjadi pegawai vertikal atau kembali ke pemda dirasa perlu dikerenakan ada beberapa pegawai yang bekerja kurang optimal disebabkan pegawai tersebut menganggap dipekerjakan pada Badan Narkotika Nasional Provinsi Bengkulu hanyalah sementara sehingga tidak merasa memilki tanggung jawab totalitas dengan asumsi ketika menemukan kesulitan mereka masih bisa kembali ke pemda Bengkulu Hal tersebut dikarenakan belum adanya kebijakan megenai pengusulan nama-nama pegawai yang akan menjadi pegawai pusat oleh Badan Narkotika Nasional Provinsi Bengkulu. Pada realitanya pegawai yang telah memilih untuk bergabung menjadi pegawai vertikal memiliki prestasi kerja yang lebih baik dari pada pegawai pemda yang dipekerjakan baik dari disiplin pegawai dan hasil kerja yang memuaskan sesuai dengan SOP yang ada.

Dengan kata lain menurut respoden pegawai Badan Narkotika Nasional Provinsi Bengkulu variabel Komitmen Organisasi memiliki pengaruh yang terkait terhadap kinerja. Para pegawai pemda dirasa perlu untuk menentukan pilihan agar dapat totalitas dalam melaksanakan tugas guna peningkatan kinerjanya.

\section{KESIMPULAN}

1. Berdasarkan hasil uji hipotesis 1 diperoleh Budaya Organisasi, Gaya Kepemimpinan dan Komitmen Organisasi memiliki pengaruh positif pada kinerja pegawai Badan Narkotika Nasional Provinsi Bengkulu. Realitanya masih kurangnya keterbatasan pegawai yang memiliki kemampuan dalam mengoperasikan komputer, guna meningkatkan kinerja para pegawai Badan Narkotika Nasional Provinsi Bengkulu hendaknya diberikan pelatihan mengenai cara mengoperasikan komputer kepada para pegawai yang belum memiliki kompetensi tersebut. Selain itu hendaknya perlu ditingkatkan lagi motivasi para pegawai Badan Narkotika Nasional Provinsi Bengkulu yang merasa sulit dan kurangnya kemauan untuk belajar mengoperasikan komputer. karena mengingat Badan Narkotika Nasional Provinsi Bengkulu sudah mengadopsi basis kompitesisasi dan teknologi informasi sebagai upaya sinkronisasi program kerja pusat dan daerah. Hal ini sebagai upaya tindak lanjut permasalahan keterbatasan sumber daya manusia dalam hal sinkronisasi program pusat dan daerah yang berbasis teknologi informasi sehingga adanya optimalisasi kinerja para pegawai Badan Narkotika Nasional Provinsi Bengkulu.

Selain itu, mengingat pada Badan Narkotika Nasional Provinsi Bengkulu, setiap bidang terdiri dari pegawai negeri sipil baik tenaga medis maupun non medis dan aparatur POLRI yang memiliki latar bekalang budaya yang berbeda untuk itu perlu adanya komunikasi yang baik sehingga seluruh kegiatan yang ada dapat diorganisis melalui kerja sama tim.

2. Berdasarkan hasil uji hipotesis 2 diperoleh Budaya Organisasi memiliki pengaruh positif pada kinerja pegawai Badan Narkotika Nasional Provinsi Bengkulu. Pada Badan Narkotika Nasional Provinsi Bengkulu terjadi perubahan rantai komando yang dulunya desentralisasi menjadi sentralisasi karena semua peraturan merujuk pada peraturan Badan Narkotika Nasional sesuai dengan isi dari diterbitkan Peraturan Presiden RI No. 23 Tahun 2010 Tentang Badan Narkotika Nasional sehingga implementasinya keputusan yang diambil oleh Kepala Badan Narkotika Nasional Provinsi Bengkulu pada bersifat sentralisasi. Perubahan dari desentralisasi menjadi sentralisasi tentunya menimbulkan perubahan pola pelaporan akuntabilitas dan tata kelola serta budaya pada Badan Narkotika Nasional Provinsi Bengkulu sehingga perlu adanya sosialisasi terkait dengan perubahan agar tidak terjadi miss komunikasi yang mengakibatkan kurang optimalnya kinerja para pegawai.

3. Berdasarkan hasil uji hipotesis 3 diperoleh Gaya Kepemimpinan memiliki pengaruh positif pada kinerja pegawai Badan Narkotika Nasional Provinsi Bengkulu. Realitanya pada Badan Narkotika Nasional Provinsi Bengkulu yang dipimpin oleh POLRI memberikan perhatian khusus pada beberapa pegawai yang melanggar disiplin dengan memberikan sanksi yang tegas sesuai dengan instruksi yang diberikan oleh Kepala Badan Narkotika Nasional Provinsi Bengkulu sebagai upaya peningkatan kinerja. Dalam hal ini Badan Narkotika Nasional Provinsi Bengkulu hendaknya memberikan sanksi pada pegawai yang melanggar aturan dengan tegas tanpa pilih kasih agar menjadi koreksi bagi mereka 
yang diberikan sanksi dengan harapan bisa lebih disiplin dalam rangka peningkatan kinerja pegawai dilingkungan Badan Narkotika Nasional Provinsi Bengkulu.

4. Berdasarkan hasil uji hipotesis 4 diperoleh Komitmen Organisasi memiliki pengaruh positif pada kinerja pegawai Badan Narkotika Nasional Provinsi Bengkulu. Realitanya masih terdapat pegawai yang hanya sekedar ikut-ikutan untuk dipekerjakan oleh pemda Provinsi Bengkulu menjadi pegawai pada Badan Narkotika Nasional Provinsi Bengkulu yang belum memiliki rasa tanggung jawab yang penuh terhadap tugas yang diemban dan kemudian berdampak pada kurang optimalnya kinerja para pegawai. Dalam hal ini Badan Narkotika Nasional Provinsi Bengkulu hendaknya membuat kebijakan tentang pengajuan usulan peralihan status kepegawaian dari pegawai pemda menjadi pegawai pusat dengan range waktu tidak terlalu lama sehingga para pegawai yang memilih menjadi pegawai vertikal dilingkungan Badan Narkotika Nasional Provinsi Bengkulu memilki rasa tanggung jawab yang penuh terhadap tugas yang diemban guna meningkatkan kinerja para pegawai dan pegawai yang memilih kembali ke pemda Bengkulu untuk segera ditindak lanjuti untuk dikembalikan kepada satuan kerja pada pemda Provinsi Bengkulu.

\section{DAFTAR PUSTAKA}

Allen, NJ., Meyer PJ. And Smith CA, 1993, Commitment to Organizations and Occupations : Extension and Test of a Three-Component Conceptualization, Journal of Applied Psychology, Vol. 78, No. 4

Cushway dan Lodge, 2000, Managerial Behaviors and Work Group Climates as Predicions of Employee Outcomes, Human Business Development Quartely, Vol. 6, 173-203

Hofstede, Geert, 2004, Culture's Consequences, Second Edition, Thosand Oaks, London, New Delhi

Janseen, Onne. 1998. Performance Management, Jakarta: Gramedia Pustaka Utama.

Kotter, JP dan J.L. Heskett, 1997. Corporate Culture and Performance, Jakarta: PT. Prenhallindo

Kreitner, Robert; dan Kinicki, Angelo, 2005, Perilaku Organisasi, Buku 1, Edisi Kelima, Salemba Empat, Jakarta

Ma'sud, 2004, Manajemen Sumber Daya Manusia", edisi 3, BPFE Yogyakarta

Nouri. H, Parker. RJ, 1998. The Relationshif between Budget participation and Job Performance the Roles pf Budget Adequacy and Organizational Commitment, Accounting Organization and Society. Vol 23.

Schein, 1992, 1994, The Contribution of Total Quality Management to a Theory of Work performance, Academy of Management Review, Vol 19 No.3, pp 210

Siagian, P.S., 1997, Organisasi Kepemimpinan dan Perilaku Administrasi, Jakarta: Gunung Agung

Sing-Sengupa, 2004. Organizational Cultureand Leadership (second edition) San Fransisco, Jossey- Bush Publisher

Stoner, James A.F; Freeman, R. Edward; Gilbert JR, Daniel. R, 1996, Manajemen, Jilid I, PT Bhuana Ilmu Populer

Timpe. 1993. Human Resources Management. USA : Prentice- Hill

Williams, 1998, The Contribution of Total Quality Management to a Theory of Work performance, Academy of Management Review, Vol 19 No.3, pp 210

Yuwalliatin, 2006, Pengaruh Budaya Organisasi, Motivasi, dan Komitmen Terhadap Kinerja Serta Pengaruhnya Terhadap Keunggulan Kompetitif, EKOBIS, Vol. 7 No.2 